http://dx.doi.org/10.4314/ejotmas.v7i1-2.33

\title{
ISSUES IN PREVENTING MOTHER-TO-CHILD TRANSMISSION OF HIV: A LIBERAL HUMANIST READING OF SONG OF A GOAT
}

\author{
*Dennis A. MORDI, Ph.D.
}

\begin{abstract}
This article examines the issues in preventing mother-to-child transmission (PMTCT) of HIV in rural communities in Nigeria. It assesses the cultural practices that propel mother-to-child-transmission (MTCT) vis-à -vis their implications on development. It uses J.P Clark's play, Song of a Goat as a premise to argue that the dramatic characters in the play as well as traditional symbols and idiolects embody diverse tropes which touch on the components of PMTCT such as stigmatisation, gender inequality and discrimination of persons living with HIV. It further contends that the in/action of the dramatic characters in the play's plot as well as some aspects of the thematic thrusts convey diverse perspectives which community workers should consider in designing, with participation of beneficiary communities, communication strategies for effective public health awareness campaign and PMTCT intervention programmes. The paper uses liberal humanism as a theoretical bastion to maintain that cultural practices are catalysts that are capable of increasing or reducing PMTCT across rural communities in Nigeria. It concludes that intervention workers should as well look in the direction of play-texts to understand the cultural dynamics at play in apprehending the extant realities in communities and working with the people to reflect on their contexts with a view to forging ways that can instigate behavioural change.
\end{abstract}

Keywords: PMTCT, Liberal humanism, Dramatic characters, HIV, Impotence, Infidelity

\section{Introduction}

Liberal humanism is a philosophical and literary theory that avers that humans are accountable to themselves and not to any deity or religious creeds. Liberal humanism also posits that literature is timeless and concerns what is persistent in human nature. The liberal humanism

\footnotetext{
*Dennis A. MORDI, Ph.D. is of the Development Communication Unit, Institute of Human Virology, Nigeria

Email: damordi@yahoo.com
} 
theory was popularised in the late 1800s and early 1900s. Although humanism as a thought began in 1400 as way of giving prominence to humans than to any celestial being, followers of this movement today believe that religion is an aberration because they can seek and live good lives, scientifically and technologically without adhering to any religious or superstitious beliefs. Humanists are concerned with personal happiness, welfare of humankind and the protection of natural environment expounded in the principles of mutual respect and development of every human being, and not on beliefs held in the absence of data and proofs.

Lamont (1997, p.13), who sees humanism as a principle for ordinary men and women in search of ideal and useful lives, defines humanism as "a philosophy of joyous service for the greater good of all humanity in this natural world," using reason and scientific method to resolve ethical and teething troubles. Indeed, one of the proponents of the theory that literature is timeless and concerns what is persistent in human nature, though with a revitalized sense of human solidarity based on Christian faith is Maurice, who argues that the study of English literature links readers to what is stable and continuing - in their uniqueness and the relationship of the unlearned reader to books as a type of 'friendship' (Buckridge, 2009). For Maurice, literature would serve to reveal the mind and personality of the writer, hence, the need to read the books of remarkable men and women not books that have no moral influence, feelings and interest (Dorrill, 2017). The implication is that readers of authors so endowed with imagination will become themselves gifted and emancipated from wisdom and traditions that are uncharacteristic with the present age.

Another proponent of liberal humanism that emerged in the latter half of the nineteenth century Europe, especially in Germany, is Immanuel Kant, whose thought emphasises the value of human beings as being above all prices because of their possession of self -conscious desires and goals, and irrational capability of making their own decisions through conducts impelled by reason (Rachels, 1986). Other humanism exponents include Protagoras of Abdera who became famous for his claim that "man is the measure of all things;" Albert Einstein, Sigmund Freud, Walter Lippmann, Jean Paul Sartre and Thomas Mann are some of the theorists whose thoughts inspired the world to rely on individualism (Ajei \& Ramose, 2008; Lamont, 1997). There are other forms of humanism which include Renaissance Humanism that developed in the Middle Age with the focus on the ability of humans to differentiate between truth and falsehood using their thinking ability. It is regarded as a revolt against medieval Christianity. Another is Enlightenment Humanism, which started in France in the 17th century and was critical of organized religion and 
relied more on human reason devoid of spiritual and cultic twist of the Renaissance thought; and the Romantic Humanism which laid emphasis on human feeling than on human thought. Others are Religious Humanism which focused on morality, Secular Humanism which stressed on human freedom, Democratic Humanism, Literary Humanism, Modern Humanism, Cultural Humanism, and African Humanism. All these dimensions of humanism have corresponding line of position on the understanding of human nature and have a common struggle to liberate humans from dependency (Lamont, 1997). This paper discusses the relevance of the liberal humanism theory using J.P Clark's Song of a Goat, to encapsulate the sexual, maternal and child and reproductive health issues portrayed in the play with a view to illustrate the cultural and social patterns in the play-text that can increase the risk factor for Human Immunodeficiency Virus (HIV) infection in rural communities in Nigeria. The concept of liberal humanism in this regard could provide insight on how to explain the risk factors for HIV infection and how to identify proactive measures that development agencies such as the Institute of Human Virology Nigeria (IHVN), one of the leading local organisations addressing the HIVIAIDS epidemic in Nigeria can adopt to attain higher awareness campaign outcomes for preventing mother-to-child transmission of HIV rural communities in Nigeria.

\section{Conceptual Premise of Transmitting HIV}

To understand the mode of transmission of HIV, it is important to define what it is. It is a virus that steadily attacks the body's immune system making the person with the virus defenseless and prone to opportunistic infections such as tuberculosis, diarrhea, pneumonia and malaria (Bartlett and Finbeiner, 2006). The major transmitting mode of the virus is through sexual intercourse. Other means include sharing injection or needle with a person living with HIV; HIV positive mother to her child before or during birth and through breast feeding; and blood transfusion (P. S. Dakum, personal communication, December 5, 2015). However, the major means that children acquire HIV is through Mother-to-Child Transmission (MTCT) of HIV, which is the midpoint of this paper. The children that are living with HIV in Nigeria are 380,000 . An estimated 60,000 children are born annually with HIV in Nigeria, which accounts for $30 \%$ of the global mother- to-child transmission of HIV burden (UNAIDS, 2015) - ranking Nigeria with the highest number of HIV infections among children in the world (National Agency for the Control of AIDS (NACA), 2019; Aluko, 2019). Prevention of Mother-to- Child Transmission of HIV (PMTCT) is the prevention of the spread of HIV from a woman living with the virus to her child during 
pregnancy, childbirth and breastfeeding. According to the Federal Ministry of Health and the UNICEF (2007) and National Agency for Control of AIDS and the UNICEF (2016), 90\% of all HIV infection in children occurs through mother-to- child transmission during pregnancy through the placenta, labour and delivery, and during breastfeeding. Olugbenga-Bello et al. (2013, p. 399), claim that "the fastest growing group of adults living with HIV is women [and] as more women contract the virus, the number of children infected in utero, intra-partum, and during breastfeeding has been growing."

The commemoration of the first day of December of every year as World AIDS' Day to demonstrate continuous support for people living with HIV, and to honour those who have died of AIDS, shows that the issue of how to effectively stop the spread and eliminate HIV is a global concern. The United Nations global programme to bring the disease under control by 2030 will be possible if the preponderance of infection amongst women and children is dealt with particularly in sub-Saharan Africa which shoulders $75 \%$ of the global burden of the disease. Over 35 million people were living with the virus in the world and 15 countries were most affected (UNAIDS, 2014). Top on this list is South Africa, $18 \%$ followed by Nigeria with $9 \%$ HIV disease burden of about 3.2 million people. The others are India, 6\%; Kenya, 5\%; USA, Mozambique, Uganda, Tanzania and Zimbabwe with $4 \%$ each; Zambia and Malawi share 3\% each whereas China, Ethiopia, Russia and Brazil post $2 \%$ each. The rest of the world bears $27 \%$. The number of people globally living with HIV has slightly gone upto37.9 million people in 2018 (UNAIDS, 2019).Also, the number of people living with HIV in Nigeria has now decreased to an estimated 1.9 million, according to UNAIDS and the National Agency for the Control of AIDS (UNAIDS, 2019), but the estimated 800,000 not on treatment (NAIIS, 2019) is a gap requiring attention of all stakeholders in the fight against the spread of the disease.

In Nigeria, HIV infection which used to be found more among males had shifted to women and children (Olugbenga-Bello et al., 2013). The implication is that more children are now more vulnerable to new HIV infection. Information from the Federal Ministry of Health (FMoH) shows that "there is a growing HIV and AIDS epidemic among children, who acquire the infection through MTCT" (FMoH, 2007; NACA, 2019; Aluko, 2019). Despite this, only $30 \%$ of eligible women in Nigeria have access to PMTCT services in contrast to South Africa's $80 \%$ and Botswana's $100 \%$ (UNAIDS, 2014). The implication is that Nigeria accounts for more than $30 \%$ of the global PMTCT gap (Oladele et al.,

2017). Some of the reasons for low uptake of PMTCT services include: low Ante-natal Care (ANC) attendance, stigma and discrimination of people living with HIV; low level of male involvement in PMTCT; and 
cultural, religious and linguistic challenges (Mordi, 2018). The cost implication in terms of financial, human and material resources to eliminate mother-to-child transmission of HIV is another. For example, it costs A5 million per infection to manage a patient using Option B+, which is a guideline recommended by World Health Organisation for all pregnant women to receive treatment that provides them with antiretroviral therapy for life without minding their CD4 count. Option B will cost N7.9 million per infection (Adesina \& Alkenbrack, 2014). CD4 count is a measurement of the white blood cells that ward off infection. It is an essential part of the human immune system. When these cells become depleted as a result of HIV infection, the body of the affected persons becomes vulnerable to many infections.

This paper discusses the relevance of the liberal humanism theory using Song of a Goat, to emblematically highlight some of the sexual and reproduction health issues relating to the spread of HIV in rural communities in Nigeria, especially the ljaw communities of the South South region of the country, which have the highest HIV prevalence at 3. $1 \%$ compared to the national HIV prevalence of $1.4 \%$. The relevance of the theory herein is not absolute because the play also brought to the fore the contentious side of liberal humanism that relies so much "upon reason as the final arbiter of what is true and good and beautiful" (Lamont, 1997). This claim puts African humanism-belief in deity or gods through ancestries in the spotlight. Africans are said to believe in the supernatural. Nevertheless, technological advancements seem, arguably, to be shifting the attention, or, watering down the religiosity that many Africans once held. Song of a Goat is a play written by J.P. ClarkBekedermo to illustrate the communal life of an ljaw fishing community as an archetype of where spiritual and magical ceremonies hold sway in solving cultural and moral problems such as infidelity, bareness, childishness and adultery. In this connection, we look closely at the presentation in a dialogical flow laced up with emotions, sacrifices and misfortunes and how Clark's play could help curb the spread of HIV by understanding the risk factors for the spread of HIV and its vertical transmission to children in coastal communities of Nigeria.

\section{Liberal Humanist Reading of Song of a Goat}

This play brings to fore the universal truth about the issues of impotence, infidelity and sexual and reproductive health, which are timeless. The two main characters in this classical tragedy are Zifa and Ebiere, who suffered this human jeopardy that has been recurring through the ages. Ironically, the issues of infertility are seen as the problem of women whereas it takes two to make a baby. The search for solution has led to many untold problems for couples. Here, the 
search for a child takes Ebiere to Masseur (their family doctor) to be sure she is not barren and receives a diagnostic assurance that her womb is fertile: "open and warm as a room." Interpretatively, this may have evocatively sown the seed that led to the adultery between Ebiere and Tonya, Zifa's brother. The play is alive because it is dialogical and shows that living in any community is about performances and conversations of people with different motives. The play is full of events with setting in an ljaw community where impotence attracts shame, moments for domestic chores, minding of fishing nets, banters between brothers, acts of seduction leading to sexual intercourse, pregnancy and miscarriage, successful suicide attempts and mourning, which help in understanding the behaviour of the characters in the play. It generates tension to be seen in moments of arguments, jokes and crying that teach lessons, which enhance life and many other values such as patience and forgiveness. The play shows the futility of anger, unfaithfulness, selfrejection and acts of deceit, which are common with human beings.

Liberal humanists use some literary critical guidelines to interpret a text or phenomena. For example, the theory posits that good literature is timeless. According to Barry (2002), timelessness is the kernel of good literature, which somehow surpasses the limitation and uniqueness of the age it was written in, thereby discussing what is endless in human nature. In Song of a Goat, the issue of infertility or impotence is timeless and a common concern especially in African society. Mother- to-child transmission of HIV is just one of the modern issues of child and maternal health revolving around conception, delivery and nursing of babies. Being pregnant, giving birth and taking care of babies will remain constant experiences for humans. Zifa is a fisherman and part-time ship pilot in one of the creeks in the Niger Delta and his wife Ebiere, who had a child bearing issue. The play speaks to what is constant in human nature - the issue of couples facing difficulty having a baby and the problem of impotence in Ebiere's conversation with Masseur, as she laments: Oh, how I wish l'd die, to end all this shame, all this showing of neighbours my fatness when my flesh is famished! ....It isn't there, it isn't there at all. For all its stoutness

and size. There isn't just pith to the stout staff (Three Plays, 2008, p. 4). Gender issues (discrimination) that are constant in human nature plays out when Masseur advises Ebiere on how to solve her inability to conceive for Zifa. Masseur's counsel shows how some cultures can be unfair to women, particularly in African communities. Hear her:

....If both families cherish each other so

much, a good proposition would be for your

husband to make you over to another in his 
family....He should make you over to his

younger brother. That'll be a retying of

knots, not a breaking or loosening of them.

(Three Plays, 2008, p. 4-5)

The search for solution to child birth has led to many untold problems for many couples. One of these problems is infidelity, which gives birth to other problems such as HIV infection. Many homes today have children born outside marriage as a result of a wife or husband cheating purposefully or unintentionally because of the pressure to have a child or find sexual satisfaction. In Song of a Goat, the search for a child takes Ebiere to Masseur to be sure she is not barren and receives a diagnostic assurance that her womb is fertile: "open and warm as a room." Many people in rural communities in Nigeria prefer going to Traditional Birth Attendants (TBAs) and herbalists for sexual and reproductive health issues instead of public health centres for reproductive health antenatal care services, which are often the gateway to access prevention of mother-to-child transmission of HIV services. According to Mfrekemfon \& Okere (2015), pregnant women still have confidence in the efficacy of the TBAs' local herbs, concoctions and prayers given to them before and during delivery despite the high risk associated with them.

The play did not tell us the kind of instruments that Masseur uses to examine women who consult with her. However, it may not be groundless that sharp objects and unsterilized knives are some of her working tools because from the play we can deduce that Masseur is a Traditional Birth Attendant (TBA). Sharp objects, needles used on a person with HIV can infect others. Zifa also receives counsel from Masseur on what he needs to do to overcome a curse that makes him impotent just like many husbands of women living with HIV receive counsel from health workers to go for HIV test to know their status and seek treatment if they test positive to HIV. Zifa refuses to heed to Masseur's advice and the result proved fatally costly. Correspondingly, death will be what will happen to a man whose wife is living with HIV and refuses to go for HIV test and treatment.

Today, just like in the past and in other parts of the world, many couples in rural African communities seek solutions to their infertility by visiting prayer houses, shrines, oracles, herbalists and even quack doctors. Ugboaja et al. (2018) while doing a secondary analysis of 2013 Nigeria national demography and health survey, states that rural women prefer delivery with TBAs because they know and respect the cultural and social norms of the people, and because rural women face multiple challenges in accessing health care such as poverty, lack of health facilities, long distance to health facilities and lack of 
communication. For others, especially in urban areas, who can afford the cost, baby factories, artificial insemination and use of surrogate mothers have become options to have babies. According to Makinde et al. (2016), these options could be found in houses, hospitals and orphanages that have been adapted for young girls and women to give birth to children for sale on the black market, often to childless couples. Zifa and Ebiere also live in a society that finds "surrogate" mothers or fathers to cushion the effects of childlessness, even if it means using a relation to impregnate or conceive for the other. This is a norm in the setting of the play that couples go through accompanied by some tradition of cleansing or rituals to avert a curse that may become a problem later. Zifa's family is cursed and needs the sacrifice of a goat to appease the gods, which he later did but with anger defiling the goat because of the Tonya slept with his wife.

Song of a Goat provides some elements of liberal humanism. Liberal humanism's credence that a human being is fundamentally good is problematic in case of Ebiere and Zifa because "the heart is deceitful above all things, and desperately wicked: who can know it?" (Jeremiah 17: 9, King James Version). In fact, "while belief in God is not needed to be or do good, the existence of God is necessary for the existence of goodness and for any ultimate justification for being and doing good" (Honeycut, 2012). Tonye in Songs of a Goat is described by his elder brother as a "noon day thief" because he commits adultery with his brother's wife and even impregnates her. According to Ellis (2012), to be morally fair towards others and to respect their rights to liberty, liberal humanism requires that we behave with honesty and compassion. So, there is nothing good in this amorous misbehaviour of a man who in spite of his guilt could repugnantly defend his action thus: "I am no noon- day thief! If you leave your piece of cloth in the open, at night, what becomes of it?" But does leaving his piece of cloth in the open at night permit it to be tampered with without his consent in the name of doing well according to tradition? If Tonye were to have an HIV infection, Zifa's wife Ebiere would have been infected with the virus or even Tonya - and had Zifa not committed suicide and the baby in her womb not died, both could have contracted HIV. Then the circle of infection would continue and the whole community will be at risk of being ravaged by the epidemic. Liberal humanism advances another problem when it discountenances the importance of belief in God or gods, an aspect of humanism that regulates the conduct of human beings. In many communities of the Niger Delta in Nigeria, which is the setting of this play, had Zifa offered a goat to appease for the sin of his father on time, the tragedy that befall him and his family could have been averted like that of Ogun's wife who "brought forth a child," having done what the gods demanded 
from her. In African humanism, "God is regarded not just as the originator, creator or sustainer of the universe and especially the father of the human person, $\mathrm{He}$ is more so, regarded as the source of every individual person's life" (Eleojo, 2014).

\section{Issues of PMTCT in Song of a Goat}

Problems of impotence, infidelity, infertility, gender issues, intrauterine death, stigmatization and discrimination, which are captured in Song of a Goat, are issues that can increase the risk of HIV infection in a rural community and affect the quality of life of the people, which ironically is the quintessence of liberal humanism. The easiest and primary mode of acquiring HIV is through heterosexual intercourse and women of child -bearing age are more at risk due to biological, socioeconomic and cultural reasons (FMoH, 2007). In the case of Ebiere in this play, the culture permits her to have sex with another man or the brother of her husband as a solution to his impotence. Masseur, the community's gatekeeper reiterates this stance respectively:

Well, your gates are intact as their keeper cannot even touch them. Someone has to go in or they will take rust. (Three Plays, 2008, p. 4)

I understand your feelings, understand them very well. But you are young still as I say, and do not know the ways of our land. Blood of goat so large a cowry may pass thro' its nose, a big gourd of palm wine and three heads of kola-nut split before the dead of the land, and the deed is done. (Three Plays, 2008, p. 4-5)

The above may not be the only reason for the Ebiere's infidelity with Tonye her husband's younger brother because she sounds sexually starved and frustrated. Hear her before Masseur: It is not my fault. I keep my house open by night and day but my lord will not come in. (Three Plays, 2008, p. 3). This kind of disposition can lead to unprotected sex that can cause sexually transmitted diseases (STDs) such as syphilis, gonorrhea and herpes that can threaten the life of unborn babies and affect the woman's health and her ability to give birth. HIV can also be contracted from infected semen, fluids and blood during sex. On a curious but interpretive note: What led to Ebiere's stillbirth? Could it be that the STI or HIV she may have acquired as a result of frolicking with Tonye caused the stillbirth she had later? To 
tackle the issues that could spread HIV revealed in Song of a Goat, there is need to develop an appropriate communication strategy that recognizes the culture, beliefs and attitudes of beneficiary communities and the plight of women who are suffering from gender inequality and sexual lack as a result of the impotence or demise of their husbands since escapades such as Ebiere's committing adultery with her husband's younger brother could be a manner for many HIV infections that require interrogation and intervention. $A$ communication strategy that discourages adultery and premarital sex and optimizes cultural values that abhor infidelity in marriage and sex before marriage will help stem the spread of HIV - more than the promotion of condom use which even though useful does not prevent infection $100 \%$ all the time.

Another problem that health communication must solve to guarantee the wellbeing of communities is the sensitisation of people to stop stigmatising and discriminating people living with chronic diseases such as HIVIAIDS, tuberculosis and cancer. "Stigma and discrimination have continued to encumber efforts to end HIV in Nigeria (Omoera \& Emesaelu, 2016). Agencies of government should enforce the anti-HIV stigma and discrimination law to deter people from stigmatising those living with the virus" (P. S. Dakum, personal communication, December $1,2015)$. Though not told in the story that they were HIV infected, Ebiere and her husband face stigmatisation, scorn and blame as a result of Zifa's impotence and were apt in stating so. Hear Ebiere: Oh, how I wish l'd die, to end all. This shame, all this showing of neighbours my fatness when my flesh is famished! (Three Plays, 2008, p. 4). Zifa expresses his powerlessness in this vituperation:

You talk of help. What help can one expect

That is placed where I stand? People Will

only be too pleased to pick at me As birds at

worm squirming in the mud. What, Shall I

show myself a pond drained dry Of water so

their laughter will crack up the floor Of my

being? (Three Plays, 2008, p. 6)

Zifa and Ebiere's self-stigmatisation illustrates similar dilemma that people living with HIV face, which is another problem that communication must tackle in the prevention of HIV among women of child-bearing age whose husbands' low involvement in PMTCT is worrisome. Zifa exemplifies this issue when he says: Next everybody would be saying, there goes the cock with the flaming red crest. But touch the thing and you'll find it colder than dog's nose (Three Plays, 2008 , p. 11). Masseur proves to be an effective gatekeeper, who is connected to everyone in the community and is well listened to. 
Therefore, HIV intervention programmes must involve gatekeepers such as Village Heads, Town Criers and Community leaders who begin, continue and sustain conversations that improve the wellbeing of a community. It is significant in this regard that Masseur starts the conversation in the play with this prologue: your womb. Is open and warm as a room. It ought to accommodate many (Three Plays, 2008, p. 3). Masseur also ends the drama with this epilogue: home or on the strand, tomorrow for you spells another day and the strain, the strength of the band (Three Plays, 2008, p. 48).

Effort has been made in this paper to identify how liberal humanism using the play, Song of a Goat by J. P. Clark-Bekederemo can be understood and modified to illustrate how to prevent spread of HIV and prevent mother-to-child transmission of HIV in rural communities where culture and traditions hold sway. Although this is a liberal humanist reading of Song of a Goat, the greatest of humanity is, above all, mere human - feeble, inadequate and depends on the tides of fate and determinism (Omoera, 2007). Understanding the issues of gender, stigmatisation and discrimination of people living with HIV and culture from the perspective of communal life portrayed in the text will be useful in designing, with the participation of beneficiary communities, appropriate communication strategies for HIV intervention programmes in rural communities in Nigeria. The communication strategies must be community-specific in concept, development and implementation because of differences in settings. However, what may be obtained in all communities is the presence of gatekeepers such as Masseur who are very important in the success of health intervention programmes targeted at the rural communities - their mode of operation could be slightly different. The lessons from reading Song of a Goat from a liberal humanistic lens provide a model to participate with local communities to prevent the spread of HIV.

\section{Conclusion}

The issues captured in this play illustrate the risk factors for the spread of mother -to-child transmission of HIV in rural communities that could affect the quality of life, which is the quintessence of liberal humanism. This paper recommends the use of literature such as this play to identify social and cultural norms that increase the risk of HIV in rural communities in order to inform policy, advocacy and implementation of PMTCT programmes that fit local contexts. This is because literature mirrors the society. To tackle the HIV issues pictured in Song of a Goat, there is need to develop appropriate communication strategies that recognize the connectivity between culture and literature as it relates to sexual and reproductive health, and the plight of women 
whose husbands are impotent or challenged since escapades such as Ebiere's committing adultery with her husband's younger brother could be a manner for many HIV infections that require interrogation and intervention in rural communities in Nigeria.

\section{References}

Adesina, A. \& Alkenbrack, S. (2014). The costs and impact of scaling up PMTCT in Nigeria. Washington, DC: Future Group Health Policy Project.

Ajei, M. \& Ramose, M. B. (2008). From "man is the measure of all things to money is the measure of all things: A dialogue between Protagoras and African philosophy. Phronimon, $9(1), 72-87$.

Aluko, O. (2019, December 13). Nigeria has global highest HIVinfected babies - Health Minister. The Punch, p.11.

Bartlett, J. G. \& Finkbeiner, A. K. (2006). The guide to living with HIV infection. Sixth edition. Baltimore: The Johns Hopkins University Press.

Barry, P. (2002), Beginning theory: An introduction to literary and cultural theory. Manchester: Manchester University Press.

Buckridge, P. (2009). Taste, appreciation and the 'extramural effect' on the study of literature. Australasian Journal of Victorian Studies, 13(1), 67-80.

Clark-Bekederemo, J. P. (2008). Three plays, Song of a goat, The masquerade, The raft. Ibadan: University Press Plc.

Dorrill, J. F. (2017). Federick Denison Maurice as literary critic. The conference on Christianity and literature. Christianity and Literature, 66(2), 213-229.

Ellis, B. (2012), Social humanism - A new metaphysics. London: Routledge.

Epstein, G. (2009). Good without God: What a billion nonreligious people do believe. New York: Humanist Chaplain, Harvard University.

Eleojo, E. F. (2014). Africans and African humanism: What prospects? American International Journal of Contemporary Research, 4(1), 18-23.

Federal Ministry of Health \& UNICEF (2007). Training manual on advocacy and community mobilisation, in support of the prevention of mother-to-child transmission of HIV. Abuja: Federal Ministry of Health.

Federal Ministry of Health \& UNICEF (2007). Prevention of motherto-child transmission of HIV. Nigeria curriculum participants' 
manual, National AIDS/STD control programme (NASCP).

Abuja: Federal Ministry of Health.

Honeycut, W. E. (2012). Good without God? The necessity of theistic basis for morality. Liberty University, Faculty Publications and Presentations. Retrieved 12 June 2019, from 181.http:// digitalcommons.liberty.edu/sor_fac_pubs/181.

Lamont, C. (1997). The philosophy of humanism. New York: American Humanist Association.

Makinde, O.A., Makinde, O.O., Olaleye, O., Brown, Brandon \& Odimegwu, C. O. (2016). Baby factories taint surrogacy in Nigeria. Reproductive Bio Medicine Online, 6, 45-53.

Mfrekemfon P. I. \& Okere U. A. (2015). Traditional birth attendants and maternal mortality. IOSR Journal of Dental and Medical Sciences, 14(2), 2279-0861.

Mordi, A. D. (2018). Evaluating communication outcomes of IHVN in preventing mother-to-child transmission of HIV in selected communities in Abuja, Nigeria. Ph.D. thesis, Ahmadu Bello University, Zaria..

NACA (2019). Revised national HIV and AIDS strategic framework (2019 - 2021). Future directions for HIVIAIDS response in Nigeria. Abuja: NACA.

NACA \& UNICEF (2016). National HIV Strategy for Adolescents and Young People (2016 - 2020). Abuja, Nigeria.

NAIIS (2019). Nigeria HIVIAIDS indicator and impact survey (NAIIS) reveals progress and critical gaps in ending the HIV epidemic. Press release. Nigeria HIVIAIDS indicator and impact survey. Abuja: Federal Ministry of Health, Nigeria.

Oladele, E. A ., Khamofu, H., Asala, S., Saleh, M., Raph-Opara, U., Nwosisi, C., \& Torpey, K. (2017). Playing the catch-up game: Accelerating the scale-up of prevention of mother-tochild transmission of HIV (PMTCT) services to eliminate new pediatric HIV infection in Nigeria. PLOS ONE.

Olugbenga-Bello, A.I., Adebimpe, W., Osundina, F. \& Abdulsalam, S. (2013). Perception on prevention of mother-to-child transmission (PMTCT) of HIV among women of reproductive age group in Osogbo, southwestern Nigeria. International Journal of Women Health, 5, 399-405.

Omoera, O.S. (2007). Determinism and fate in Greek/Nigerian theatre: A comparative discourse on Sophocles' Oedipus Rex and J.P. Clark's Song of a Goat and Masquerade. Iroro: A Journal of Arts, 12(1\&2), 141-148.

Omoera, O.S. \& Emasealu, E. (2016). Media locus in changing the biases against HIVIAIDS victims in Ekpoma, Nigeria . In O. 
Okome \& M. Okhakhu (Eds.). Media studies in Nigeria: Genesis and detours (pp.625-646). Ibadan: Stirling-Horden Publishers Ltd.

Rachels, J. (1986). Kantian Theory: The Idea of Human Dignity. From the Elements of Moral Philosophy, pp. 114-17, 12223. Random House, Inc.

Ugboaja, J. O., Oguejiofor, C. B., Oranu, E. O., \& Igwegbe, A. O. (2018). Factors associated with the use of traditional birth attendants in Nigeria: A secondary analysis of 2013 Nigerian national demography and health survey. Nigerian Journal of General and Private Medical Practice of Nigeria.

UNAIDS (2019). New survey results indicate that Nigeria has an HIV prevalence of $1.4 \%$. Press release. Geneva: Joint United Nations Programme on HIVIAIDS.

UNAIDS (2019) . Global HIV statistics. Fact sheet - World AIDS day 2019. Press release. Geneva: Joint United Nations Programme on HIVIAIDS.

UNAIDS (2015). The gap report, 2014. Geneva: Joint United Nations Programme on HIVIAIDS.

UNAIDS (2015). Progress report on the global plan, 2015. Geneva: Joint United Nations Programme on HIVIAIDS. 